\title{
Anti-inflammatory and cytotoxic evaluation of extracts from the flowering stage of Celosia argentea
}

\author{
Oluwafunmilayo Dorcas Adegbaju, Gloria Aderonke Otunola* (i) and Anthony Jide Afolayan
}

\begin{abstract}
Background: This study was aimed at investigating the possible anti-inflammatory and cytotoxic effects of extracts from the flowering stage of $C$. argentea. This growth stage was chosen because of its high polyphenolic content and high antioxidant capacity.

Methods: Anti-inflammatory potential of the aqueous, acetone and methanol extracts of $C$. argentea was evaluated through the inhibition of nitric oxide production (LPS-induced) on stimulated macrophages (RAW 264.7), while MTT assay was used to assess cell viability with Silymarin as standard. Cytotoxicity of the plant extracts was evaluated on murine preadipocyte cell line (3 T3-L1) using the image-based method of two DNA-binding dyes; Hoechst 33342 and propidium iodide (PI) with melphalan as standard.

Results: Acetone extract exhibited moderate, dose-dependent anti-inflammatory activity with no significant toxicity to activated macrophages, however the aqueous and methanol extracts were unable to inhibit nitric oxide production at both trials. MTT assay and the toxicity assay revealed that the flowering stage extracts of $C$. argentea were not toxic to the RAW 264.7 macrophages and 3T3-L1 cells at all the tested concentrations $(0,2,50,100$ and $200 \mu \mathrm{g} / \mathrm{mL}$ ).

Conclusions: These findings corroborate the traditional use of C. argentea for painful inflammatory conditions and encourage its possible use as lead for the development of novel, non-toxic, anti-inflammatory agents.
\end{abstract}

Keywords: Celosia argentea, Cell viability, Cytotoxicity, Flowering stage, Inflammation, Murine cells

\section{Background}

Inflammation is a protective or healing response to tissue injury in the body. It is a process characterized by a complex cascade of reactions which can be prompted by several agents along with toxic compounds, microbes, impaired cells and accumulated exudates [1, 2]. However, uncontrolled and chronic inflammation can be deleterious to health. There is a growing body of knowledge that believes that chronic inflammation is a major

\footnotetext{
*Correspondence: gotunola@ufh.ac.za

Medicinal Plants and Economic Development (MPED) Research Centre, Department of Botany, University of Fort Hare, Alice 5700, South Africa
}

accomplice in the pathogenesis of numerous modern chronic diseases such as obesity, hypertension, atherosclerosis, type 2 diabetes mellitus, Alzheimer's, osteoarthritis, inflammatory bowel diseases, cardiovascular diseases and cancer [1]. Inflammation is usually associated with deregulation in the homeostatic mechanism of processes in human physiology $[3,4]$. Persistent inflammation as a result of tissue dysfunction invariably triggers the release of macrophages.

Macrophages are large, specialized cells present in virtually all tissues [5]. They are essential cells of the immune system that are designed as inflammatory mediators in response to an infection or detection of 
damaged or dead cells They also play critical roles in immune regulation as they have the ability to recognize, engulf and destroy target cells as a response to a variety of cellular signals [6].. Due to the fact that these phagocytic cells are mostly short-lived and negative side-effects are associated with non-steroidal anti-inflammatory drugs (NSAIDs), it becomes pertinent to search for novel antiinflammatory materials with minimal side- effects or none at all. Hence, the formulation of curatives from natural sources which can supplement the distinctive immune regulation of macrophages is vital to prevent existing and evolving chronic diseases. Studies of medicinal plants for development of modern drug have been very fruitful in the past few decades $[7,8]$ and have shown that plants possess a wide range of chemical compounds with biological activities $[9,10]$.

Celosia argentea (Amaranthaceae) also known as cock's comb or quail grass is a herb of great nutritional and therapeutic importance. The seeds, leaves, flowers and roots are known for their folkloric uses in Chinese and India traditional medicine as an antidote for snakebite, glandular swelling, uterine bleeding, leucorrhea and inflammation [11, 12]. The alcoholic extracts of the leaves of $C$. argentea have been reported to possess antidiabetic property by lowering the body weight and blood glucose of diabetic rats (alloxan-induced) by $38.8 \%$ at $500 \mathrm{mg} / \mathrm{kg}$ body weight [13]. It has also been reported that the flavonoid fraction of $C$. argentea leaves possess anti-inflammatory activity on carrageenan-induced rat paw edema and cotton pellet-induced chronic inflammatory models at $10 \mathrm{mg} / \mathrm{kg}$ body weight [11]. Recently Malomo and Yakubu [14], reported that the aqueous extract of $C$. argentea attenuated cadmium-induced oxidative stress in Wistar rats at $400 \mathrm{mg} / \mathrm{kg}$ body weight.

Due to the pharmacological significance and low cost of plant derived substances compared to synthetic drugs, much attention has been drawn to them, especially for the discovery of unique and novel anti-cancer drugs as well as therapeutic agents for treating other viral infections [15]. Therefore, cytotoxicity screening of plant extracts intended for pharmaceutical production is an important initial step when investigating possible new therapies or developing new compounds for the treatment of an ailment. This will help to detect their possible cytotoxic and harmful effects.

The study is therefore aimed to investigate the antiinflammatory potential and possible cytotoxicity of flowering stage extracts of $C$. argentea.

\section{Methods}

\section{Plant source and study site}

The plant material used for this study was harvested at the 7th week (flowering stage) of each trial from the glass house of the University of Fort Hare, Alice, South
Africa. The geographical location of the study site lies at latitude $32^{\circ} 47^{\prime}-19^{\circ} 26^{\prime} \mathrm{S}$; longitude $26^{\circ} 50^{\prime}-42^{\circ} 306^{\prime} \mathrm{E}$ and altitude of $514.70 \mathrm{~m}$. The plant was authenticated by Prof Cupido at the Giffen herbarium of University of Fort Hare and a voucher specimen (Ade/med/2017/01) was deposited at herbarium for reference.

\section{Preparation of crude extracts}

After harvest, aerial parts (leaves, stem and flowers) of the plant were rinsed with de-ionized water, oven-dried for $72 \mathrm{~h}$ at $40^{\circ} \mathrm{C}$ and pulverized with an industrial electric blender (Hamilton Beach, HBF500s series, Canada). $200 \mathrm{~g}$ of the ground sample individually in $1.5 \mathrm{~L}$ of distilled water, acetone or methanol was agitated constantly for 72 h using a shaker (Gallenkamp incubator orbital shaker). Filtered solution from the aqueous extract was concentrated to dryness in a freeze dryer, while the solvent extracts were vaporized to dryness in a rotary evaporator at their respective boiling points. The dried extracts were stored at $4{ }^{\circ} \mathrm{C}$ in a refrigerator until needed.

\section{Chemicals and cells}

All the chemicals and reagents used including glucose, pyruvate, dimethyl sulfoxide (DMSO), Griess reagent, Hoechst 33342, Propidium iodide, Cell lines and culture materials including $10 \%$ fetal calf serum, Melphalan, DMEM (PI), 3 T3-L1; RAW 264.7 cell-lines and RPMI medium were sourced from Sigma-Aldrich ${ }^{\circ}$ (Johannesburg, South Africa) and Hyclone ${ }^{\circ}$ (Thermo Fisher, Logan, UT, USA).

\section{Anti-inflammatory assay}

Cell culture RAW 264.7 macrophages were cultured in the appropriate medium containing $10 \%$ fetal calf serum (Roswell Park Memorial Institute medium (RPMI) and were inoculated in 96-well plates (at a density of $1 \times 10^{5}$ cells per well), then allowed to incubate overnight in a humidified incubator at $37^{\circ} \mathrm{C}$ and $5 \% \mathrm{CO}_{2}$ for $24 \mathrm{~h}$. The medium was replaced with aqueous, acetone and methanol extracts of $C$. argentea at concentrations ranging from 0 to $200 \mu \mathrm{g} / \mathrm{mL}$ obtained using serial dilution, with silymarin as positive control. A volume of $1 \mu \mathrm{g} / \mathrm{ml}$ of lipopolysaccharide was added to the test samples and incubated at $37^{\circ} \mathrm{C}$ for $18 \mathrm{~h}$. Thereafter, cell viability was assessed by adding $50 \mu \mathrm{l}$ of Griess reagent and medium into each well of another 96-well plate. It was then allowed to stand for $10 \mathrm{~min}$ at $27^{\circ} \mathrm{C}$. Absorbance was measured at $540 \mathrm{~nm}$ and the concentration of nitrate released into the culture medium was calculated from the slope of the standard curve as.

MTT assay Simultaneous evaluation of cell viability was determined colorimetrically by adding $100 \mu \mathrm{L}$ culture 
medium containing $0.5 \mathrm{mg} / \mathrm{mL}$ MTT to the remaining cells and allowed to stand at $37^{\circ} \mathrm{C}$ for $1 \mathrm{~h}$. The supernatants were decanted and the formazan precipitate in each well was dissolved in $100 \mu \mathrm{l}$ DMSO. Cell viability was assessed by measuring the absorbance at $560 \mathrm{~nm}$.

Cytotoxicity assay Dimethyl sulphoxide (DMSO) was used to reconstitute the extracts to give a final concentration of $100 \mathrm{mg} / \mathrm{mL}$. The resultant solution was sonicated and the murine preadipocyte cell line (3 T3-L1), was cultured in a medium of DMEM with low glucose and pyruvate, supplemented with $10 \%$ fetal calf serum. The cells were seeded into 96-well microtiter plates at a density of 3000/well and volume of $100 \mu \mathrm{L}$ per well. This was incubated at $37{ }^{\circ} \mathrm{C}$ in $5 \% \mathrm{CO}_{2}$ and $100 \%$ relative humidity for $24 \mathrm{~h}$, before the addition of test compounds to allow for cell attachment. $100 \mu \mathrm{L}$ of the aqueous, acetone and methanol extracts diluted at four concentrations $(0,50,100$ and $200 \mu \mathrm{g} / \mathrm{mL})$ was added to each well. The cells were incubated at $37{ }^{\circ} \mathrm{C}$ in a humidified $5 \% \mathrm{CO}_{2}$ for $48 \mathrm{~h}$. The treatment medium was removed from the wells and substituted with $100 \mu \mathrm{L}$ of Hoechst $33342 \mathrm{nu}-$ clear dye for $10 \mathrm{~min}$ at $25^{\circ} \mathrm{C}$. The cells were stained with $100 \mu \mathrm{g} / \mathrm{mL}$ propidium iodide (PI) for viewing and counting the number of dead cells.

\section{Data quantification}

All data were expressed as means \pm standard deviation (SD). Means were accepted as significantly different when data showed $(P<0.05)$, using one-way analysis of variance (ANOVA) and Fischer's LSD with the aid of GENSTAT 8 software.

\section{Results}

Inhibition of nitric oxide production in RAW 264.7 by extracts of the flowering stage of $C$. argentea

The inhibitory activity of flowering stage extracts of Celosia argentea against nitric oxide production in RAW 264.7 macrophages (LPS-induced) and corresponding cell viability are presented in Figs. 1 and 2 . The MTT assay was used to verify if observed inhibitions of nitric oxide production in the cell were caused by cell death or activity of the test compounds (Figs. 3 and 4). The first trial, revealed that aqueous and methanol extracts of the flowering stage of $C$. argentea did not suppress the production of $\mathrm{NO}$ in the cells compared to the untreated control. The acetone extracts however, suppressed LPS-enchanced $\mathrm{NO}$ expression in a dose-dependent manner. For the second trial, both the acetone and methanol extracts exhibited a dose-dependent anti-inflammatory activity by inhibiting $\mathrm{NO}$ production in the cells, which is comparable to the positive control. While the acetone showed better reduction of NO production in the first trial, the methanol extract of the second trial had the highest inhibitory power against NO production in the macrophages.

\section{Cell viability}

The cell viability evaluation revealed that the extracts along with the positive control were significantly $(p<$ $0.05)$ non-toxic to the macrophages and that the observed inhibitory action of the extracts was not due to cell damage. In comparison to the untreated control, Cell proliferation was observed in the acetone extract of the first trial (Figs. 3 and 4).

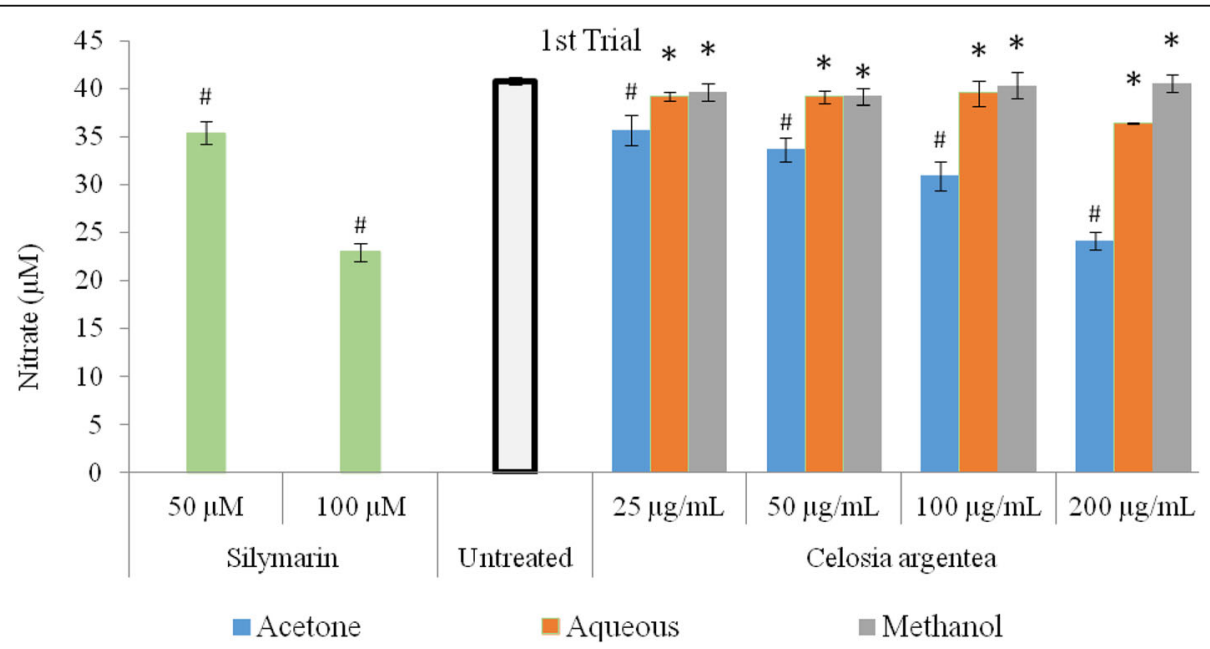

Fig. 1 Inhibition of LPS-induced nitric oxide production in RAW 264.7 cells by extracts of C. argentea. Data are mean \pm standard deviation $n=3$. Silymarin was used as positive control to illustrate inhibition of LPS induced nitrate levels * indicates no significant difference from the untreated control. (First trial) 


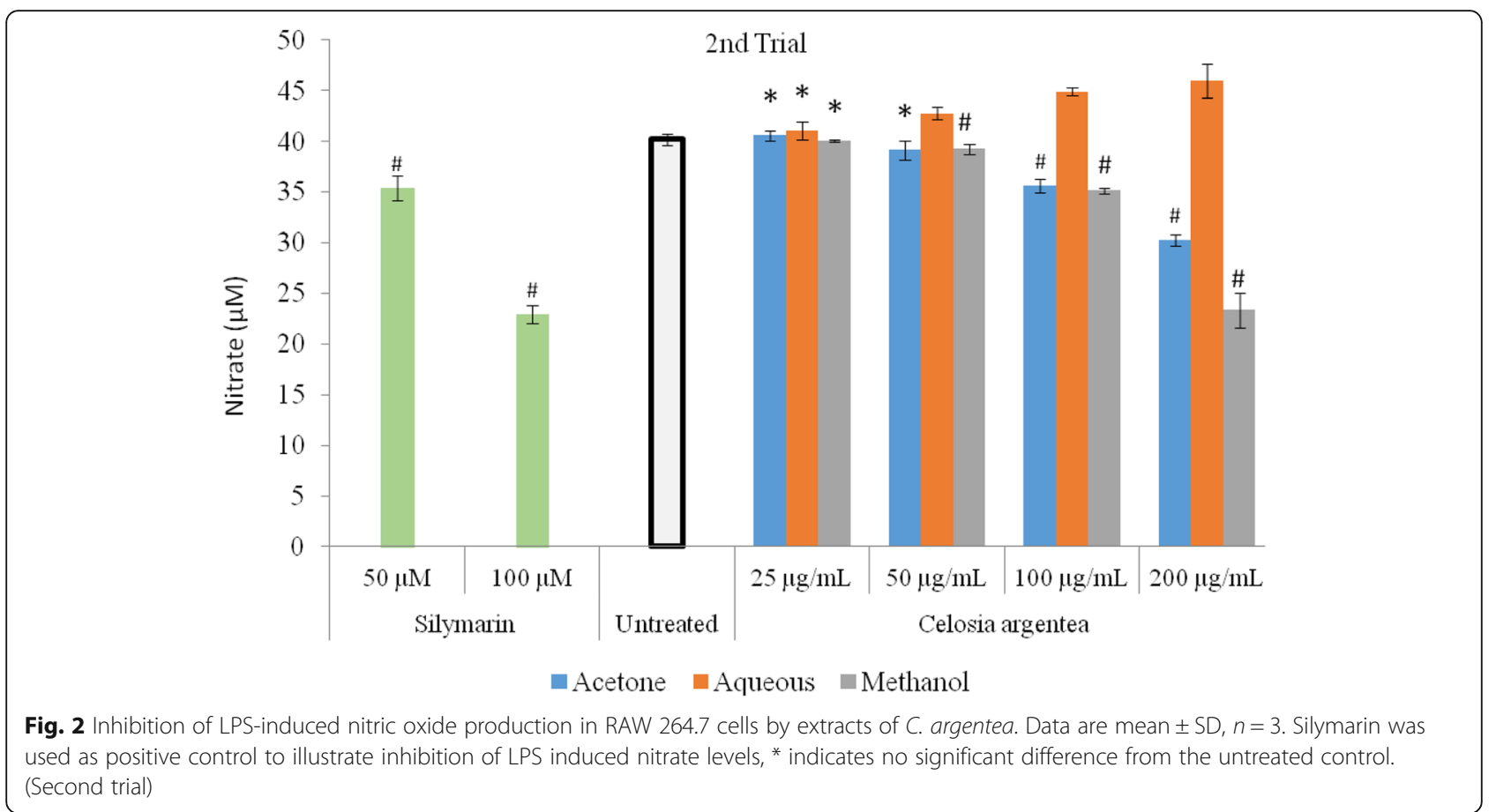

\section{Response of 3 T3-L1 cells to flowering stage extracts of $C$. argentea}

The effect of extracts of the flowering stage of $C$. argentea on murine preadipocyte cells (3 T3-L1) is depicted in Figs. 5 and 6. For the first trial, effect of the aqueous and methanol extracts was not significantly different from the untreated control at all concentrations. A dosedependent significant difference $(\mathrm{p}<0.05)$ at 100 and $200 \mu \mathrm{g} / \mathrm{mL}$ was however observed with the acetone extract compared to the untreated control, indicating low toxicity at $200 \mu \mathrm{g} / \mathrm{mL}$. For the second trial, compared to the untreated control, significant cell reduction was observed for the acetone and methanol extracts at the highest concentration, with the methanol extracts showing low cytotoxicity on the $3 \mathrm{~T} 3-\mathrm{L} 1$ cells. The positive control (Melphalan) however was significantly toxic to the cells at all concentrations.

\section{Discussion}

Nitric oxide (NO) is a key inflammatory mediator and excessive production due to the reaction of free radicals within biological systems, can result in various diseases such as cardiovascular diseases, cancer and atherosclerosis [16]. Since most diseases are associated with the

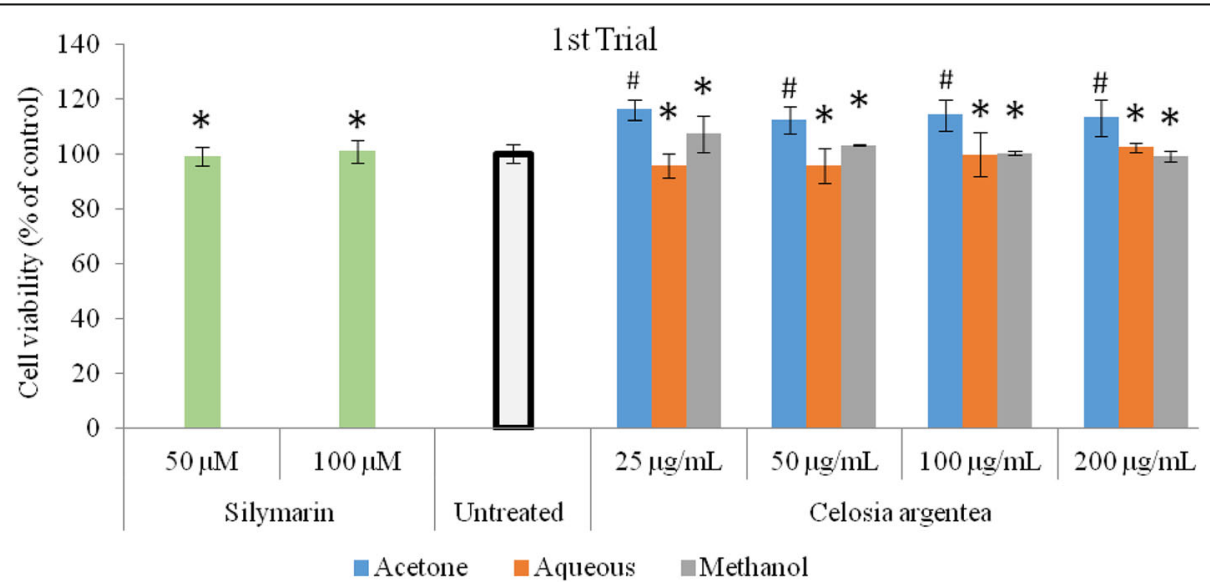

Fig. 3 Cell viability of RAW 264.7 macrophages exposed to flowering stage extracts of $C$. argentea. Data are mean $\pm S D, n=3$. Silymarin was used as positive control. ${ }^{*}$ indicates no significant difference from the untreated control; \# indicates significantly higher than the untreated control. (First trial) 


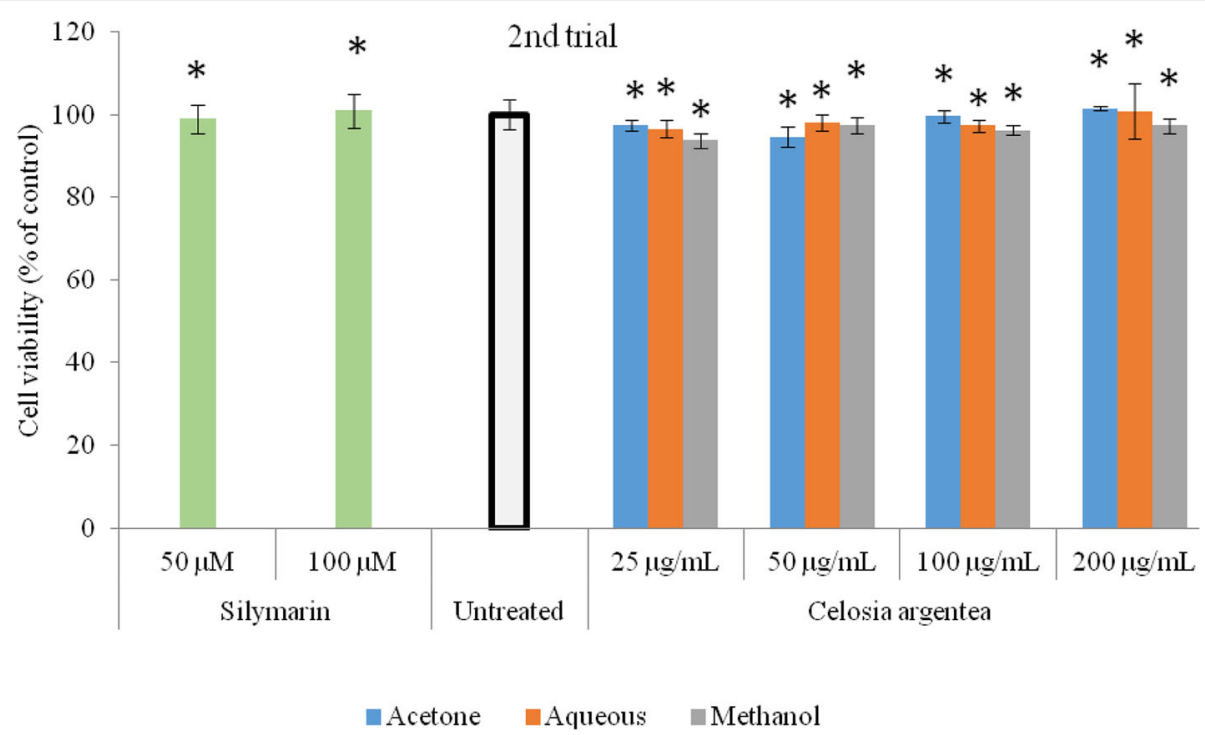

Fig. 4 Cell viability of RAW 264.7 macrophages exposed to flowering stage extracts of C. argentea. (Second trial). Data are mean $\pm S D, n=3$. Silymarin was used as positive control. *indicates no significant difference from the untreated control; \#indicates significantly higher than the untreated control. (Second trial)

disruption of homeostasis and the production of excess $\mathrm{NO}$, hence, lowering its production may be of healing advantage in various diseases induced by pathological levels of NO [17].

The acetone and methanol extracts of $C$. argentea moderately inhibited nitric oxide production in the macrophages in a dose-dependent manner. Such dose dependent inhibitory activity of $C$. argentea extracts observed in this study was similar to the findings of Malomo and Yakubu [15], who reported increased reducing power activity of $C$. argentea extract with increasing concentration. This also corroborates the findings of $\mathrm{Wu}$ et al. [18], who reported that four saponins isolated from Celosia argentea seeds (Celosin E, F, G and cristatain) had inhibitory action against nitric oxide production. The moderate inhibitory activity observed here indicates that $C$. argentea extracts could act as protective mediators against free radicals and as a regulatory agent with homeostatic activities.

Non-steroidal anti-inflammatory drugs (NSAIDs) are a wide group of cyclooxygenase (COX) inhibitors with similar therapeutic actions [18], whose interaction with

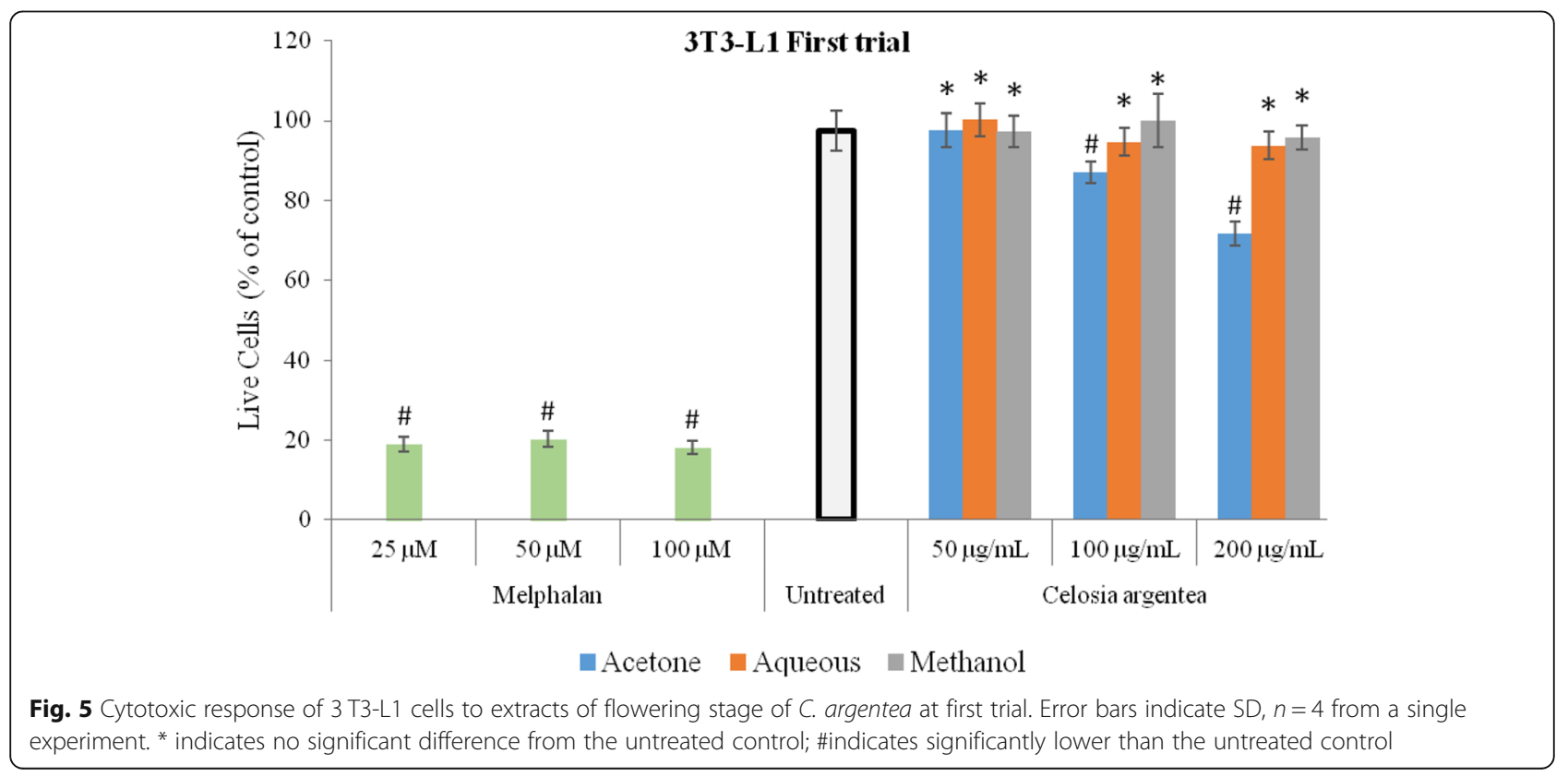




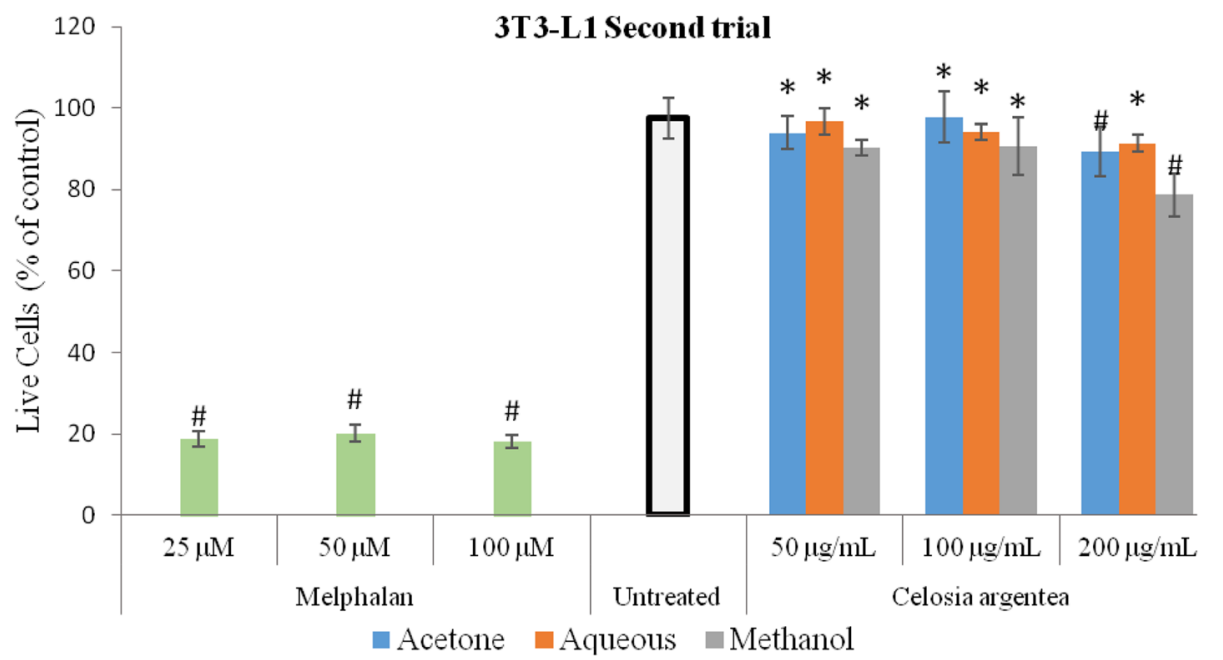

Fig. 6 Cytotoxic response of 3T3-L1 to flowering stage extracts of C. argentea at second trial. Error bars indicate SD, $n=4$ from a single experiment. ${ }^{*}$ indicates no significant difference compared tothe untreated control; \# indicates significantly lower than the untreated control

cell membranes have been shown to initiate many inflammatory phenomena and toxic side effects $[19,20]$. MTT assay revealed that none of the extracts from both trials at all concentrations evaluated in this study was cytotoxic. The significantly higher cell volume reported for the acetone extract indicate that it supports cell proliferation, which could be a positive development in wound healing, tissue repair and and aging [20]. Thus, the increased cellular proliferation observed in this study, suggest that the $C$. argentea extracts from the flowering stage could be used therapeutically for wounds, injury, repair and reversal of tissue damage.

Therapies from natural products and herbal medicines have shown promising potential as relevant complementary and alternative treatments against several aliments with the efficacy of a good number of herbal products clearly established [21]. However, the degree of use of herbal medicines does not correspond to the extent at which their safety is considered [22]. According to Vijayarathna and Sasidharan [23], any crude plant extracts at concentration of $20 \mu \mathrm{g} / \mathrm{mL}$ and below, that produces $50 \%$ of cell death within $72 \mathrm{~h}$ in vitro is cytotoxic. Worthy of note is the cytotoxic response of the 3 T3-L1 cells to all the extracts, as the percentage of dead cells was not up to $50 \%$ at all the concentrations tested. This implies therefore, that all extracts from the flowering stage of $C$. argentea are not toxic. This corroborates the reports of Rub et al [24], who stated that the methanolic extract of $C$. argentea showed no significant toxicity towards SiHa and MCF-7 cell lines. The non- toxic potential of all the extracts in this study corroborates the traditional use of the plant as vegetable and medicine; and indicates that $C$. argentea could be safely used as an anti-inflammatory agent with no side-effects.

\section{Conclusions}

This study has shown that the flowering stage extracts of $C$. argentea possess moderate inhibitory activity against the production of nitric oxide (Lipopolysaccharide-induced) in RAW 264.7 cells and corroborates the traditional use of the plant for painful inflammatory conditions, while encouraging its use for the development of non-toxic novel anti-inflammatory agents.

\section{Abbreviations}

ANOVA: Analysis of variance; DMEM: Dulbecco's Modified Eagle Medium; DMSO: Dimethyl sulphoxide; DNA: Deoxyribonucleic acid; LSD: Least significant difference; LPS: Lipopolysaccharide; MCF-7: Michigan Cancer Foundation-7; MTT: 3-(4,5-Dimethylthiazol-2-YI)-2,5-Diphenyltetrazolium Bromide); NSAID: Non-steroidal anti-inflammatory drugs; PI: Propidium iodide; RPMI: Roswell Park Memorial Institute; SiHa: Human cervical cell line

\section{Acknowledgments}

The authors wish to appreciate the financial support of Govan Mbeki Research Development Centre (GMRDC), University of Fort Hare, South Africa.

\section{Authors' contributions}

GA and OD conceptualized and designed the study. Funding acquisition was done by AJ and GA. OD carried out the investigation, analyzed and interpreted the data with the guidance of GA. OD wrote the draft manuscript. Supervision was done by AJ and GA. All authors read and approved the final manuscript.

\section{Funding}

This research was funded by grants from Professor A.J. Afolayan and Dr. G.A. Otunola. Both participated in the concept, design and interpretation of result of this study.

\section{Availability of data and materials}

The datasets used and/or analyzed during the current study are available from the corresponding author on reasonable request.

\section{Ethics approval and consent to participate}

Ethical consent for this study was approved by the University of Fort Hare Research Ethics Committee (UREC), South Africa (Reference No. AFO071SADE01). 


\section{Consent for publication}

Not applicable.

\section{Competing interests}

The authors declare no conflict of interest.

Received: 16 April 2019 Accepted: 30 April 2020

Published online: 24 May 2020

\section{References}

1. Chen L, Deng H, Cui H, Fang J, Zuo Z, Deng J, Zhao L. Inflammatory responses and inflammation-associated diseases in organs. Oncotarget. 2018:9(6):7204-18.

2. Otunola GA, Afolayan AJ. Chemical composition, antibacterial and in vitro anti-inflammatory potentials of essential oils from different plant parts of Moringa oleifera lam. Am J Biochem Biotechnol. 2018;14(3):210-20.

3. Kotas ME, Medzhitov R. Homeostatsis, inflammation and disease susceptibility. HHS Public access Cell. 2016;160(5):816-27.

4. Newcombe EA, Camats-Perna J, Silva ML, Valmas N, Huat TJ, Medeiros R. Inflammation: the link between comorbidities, genetics and Alzheimer's diseases. J Neuroinflammation. 2018;15(1):276.

5. Lavin Y, Merad M. Macrophages: gatekeepers of tissue integrity. Cancer immunol Res. 2013;1(4):201-9.

6. Soonthornsit N, Pitaksutheepong C, Hemstapat W, Utaisincharoen P, Pitaksuteepong T. In Vitro Anti-Inflammatory Activity of Morus alba L. Stem Extract in LPS-Stimulated RAW 264.7 Cells. J Evid Based Complementary Altern Med. 2017;ArticlelD 3928956:8.

7. Patwardhan B, Warude D, Pushpangadan P, Bhatt N. Ayurveda and traditional Chinese medicine: a comparative overview. J Evid Based Complementary Altern Med. 2005;2(4):465-73.

8. Yuan $\mathrm{H}, \mathrm{Ma}$ Q, Ye L, Piao G. The traditional medicine and modern medicine from natural products. Molecules. 2016;21(5):559.

9. Shad AA, Ahmad S, Ullah R, AbdEl-Salam NM, Fouad H, Rehman NU, Saeed W. Phytochemical and biological activities of four wild medicinal plants. The Sci World J. 2014;Article ID 857363:7.

10. Getasetegn M, Tefera Y. Biological activities and valuable compounds from five medicinal plants. Nat Prod Chem Res. 2016:4:220

11. Bhujbal SS, Chitlange SS, Suralkar A, Shinde DB, Patil MJ. Anti-inflammatory activity of an isolated flavonoid fraction from Celosia argentea Linn. J Med Plants Res. 2008;2(3):52-4.

12. Ghorpade P, Siddiqui A, Patil MJ, Rub RA. Pharmacognostic and phytochemical evaluation of Celosia argentea. Pharmacogn J. 2012;4(33):715.

13. Vetrichelvan $T$, Jegadeesan $M$, Devi BAU. Anti-diabetic activity of alcoholic extract of Celosia argentea Lin. Biol Pharm Bull. 2002;25(4):526-8.

14. Malomo SO, Ore A, Yakubu MT. In vitro and in vivo antioxidant activities of the aqueous extract of Celosia argentea leaves. Indian J Pharmacol. 2011; 43(3):278-85.

15. Nemati F, Dehpouri AA, Eslami B, Mahdavi V, Mirzanejad S. Cytotoxic properties of some medicinal plant extracts from Mazandaran. Iran Iran Red Crescent Med J. 2013;15(11):71-88.

16. Kim J, Kim H, Choi H, Jo A, Kang H, Yun H, Im S. Anti-Inflammatory Effects of a Stauntonia hexaphylla Fruit Extract in Lipopolysaccharide-Activated RAW264.7 Macrophages and Rats by Carrageenan-Induced Hind Paw Swelling. Nutrients. 2018;10(1):110.

17. Wu Q, Wang Y, Guo M. Triterpenoid saponins from the seeds of Celosia argentea and their anti-inflammatory and antitumor activities. Chem Pharm Bull. 2018:59(5):666-71.

18. Pignatello R, Musumeci T, Basile L, Carbone C, Puglisi G. Biomembrane models and drug-biomembrane interaction studies: involvement in drug design and development. J Pharm Bioallied Sci. 2011;3(1):4-14.

19. Auriel E, Regev K, Korczyn AD. Nonsteroidal anti-inflammatory drugs exposure and the central nervous system. In Handbook of Clin Neurology. 2014;119:577-84.

20. Boyette L, Tuan R. Adult stem cells and diseases of aging. J Clin Med. 2014; 3(1):88-134

21. Ekor M. The growing use of herbal medicines: issues relating to adverse reactions and challenges in monitoring safety. Front Pharmacol. 2014;4:177.

22. Moreira DDL, Teixeira SS, Monteiro MHD, De-Oliveira ACA, Paumgartten FJ. Traditional use and safety of herbal medicines. Revista Brasileira de Farmacognosia. Rev Bras de Farmacogn. 2014;24(2):248-7.
23. Vijayarathna S, Sasidharan S. Cytotoxicity of methanol extracts of Elaesis guineensis on MCF-7 and Vero cell lines. Asian Pac J Trop Biomed. 2012; 2(10):826-9.

24. Rub RA, Patil MJ, Siddiqui AA, Ghorpade PR, Moghe AS. Free radical scavenging and cytotoxic potential of Celosia argentea. Pharmacogn J. 2015: 7(3):191-7.

\section{Publisher's Note}

Springer Nature remains neutral with regard to jurisdictional claims in published maps and institutional affiliations.
Ready to submit your research? Choose BMC and benefit from:

- fast, convenient online submission

- thorough peer review by experienced researchers in your field

- rapid publication on acceptance

- support for research data, including large and complex data types

- gold Open Access which fosters wider collaboration and increased citations

- maximum visibility for your research: over $100 \mathrm{M}$ website views per year

At BMC, research is always in progress.

Learn more biomedcentral.com/submissions 